\title{
Student-Teachers' Perceptions of Second Language Teaching in the CBL Program: Identity Construction and Development
}

\author{
Shu-Fen Yeh* \\ Department of Applied English, Shih Chien University, 200 University Road, Neimen, Kaohsiung 84550 Taiwan
}

Corresponding Author: Shu-Fen Yeh, E-mail: susanyeh@g2.usc.edu.tw

\begin{tabular}{l} 
ARTICLE INFO \\
\hline Article history \\
Received: May 15, 2017 \\
Accepted: July 19, 2017 \\
Published: August 31, 2017 \\
Volume: 8 Issue: 4 \\
Advance access: August 2017 \\
\hline Conflicts of interest: None \\
Funding: None \\
\hline
\end{tabular}

Key words:

Second Language Teaching,

Community Service Learning,

Student-Teachers' Identity,

Social Justice

\begin{abstract}
In recent times, researchers of second language learning have suggested that second language learning is not simply a cognitive or linguistic issue, but is also a social, political, and cultural one (e.g., Atkinson, 2002; Firth \& Wagner, 1997; Larsen-Freeman, 2007). Research on studentteachers' identity (e.g., Atkinson, 2004; Day \& Kington, 2008; Wenger, 1998) also stresses the importance of identity development to help students with setting goals and learning (e.g., Olsen, 2008). Therefore, this qualitative research aimed to investigate STs' identity development and how identity transfers knowledge to facilitate the learning and teaching processes. This study applied a two-semester community-based learning program involving 40 university students and 50 elementary school students in Taiwan. It was found that negotiating multiple discourses in diverse social contexts is another dimension of learning sources for student-teachers' understanding of personal values, increasing the awareness of social responsibilities, and fashioning their personal and pedagogical identities.
\end{abstract}

\section{INTRODUCTION}

Researchers of second language learning have suggested that $\mathrm{L} 2$ learning is not simply a cognitive or linguistic issue, but also a social, political, and cultural one (e.g., Firth \& Wagner, 1997; Larsen-Freeman, 2007; Long, 2007; Zuengler \& Miller, 2006). The meaning of learning, as Wenger (1998) pointed out, is a social process and one of transforming one's ability to participate in the world and to become a valid member of a community. Reflecting Day's (2002) beliefs about learning, the purpose of learning should be related to real-life tasks to benefit individuals' learning and to foster their capacity to contribute to society. Therefore, the objective of education is no longer to convey a body of knowledge, but rather to help students with their knowledge to prepare a way to participate in the world and to engage in society.

The community-based learning (CBL) approach, an educational learning concept of linking academic work and communities, is used to place an emphasis on the ways of interacting and collaborating with members of the local learning communities and to signify the importance of creating an atmosphere of collaboration, reflection in learning communities, and its impact on the construction of one's identity (e.g., Farnsworth, 2010; Julier, 2001; Trent, 2010). Theoretically, $\mathrm{CBL}$ forms one component of teaching programs of which the aim is preparation for teaching and learning in diverse social contexts; it is another dimension of language learning and a potential new set of sources specific to the field of curriculum and teacher education research.

In the teacher education research domain, the concept of identity has been widely used in helping student-teachers (STs) with setting goals (Poupou, 2007; Gee, 2001; Fan, 2013) and with their professional development (Assaf, 2005). Researchers have argued for the influence of identity on STs' development of practice in teaching and learning. As Bullough (1997) stated, teacher educators should help STs develop their professional identity because it will influence their instructional decisions. However, the identity development process does not seem to be easily identifiable and is not stable, but some researchers have argued that it is negotiable through the process of Bakhtin's (1981) concept of negotiation voices, Gee's notion of discourse-identity (1999), and Assaf's (2005) argument of multiple discourses within a learning community. Therefore, in the past 10 years, given the significance of STs' identity, some studies have been conducted on teaching education programs to explore the process of identity formation, to redefine STs' professional identity, and to help them become more socially just teachers (e.g., Farnsworth, 2010; Gee, 2001). However, relatively few studies have specifically addressed the issue of STs' 
identity development through the social and critical perspectives incorporating CBL, such as the service learning model in second language teaching programs and teacher education (Deans, 2000) to become more socially just teachers (Farnsworth, 2010).

The community-based learning approach offers a potentially new set of learning resources for STs engaged in negotiating multiple discourses and identity negotiation and development. Within the new set of learning sources, this qualitative research employed the concept of a social and critical perspective of teachers' identity in an analysis of the process of $\mathrm{CBL}$ in second language teaching and to investigate: 1) how the process of CBL is related to STs' second language teaching and learning, and 2) how STs' perceptions of their identity development help them to transfer their knowledge to facilitate their teaching and learning processes.

\section{LITERATURE REVIEW}

\section{Learning is A Social Process and Social Interaction}

As McMahon (1997) argued, meaningful learning does not simply take place inside our minds, but is shaded by external forces. Learning is the result of social interaction, and occurs when individuals are engaged in social activities. That is to say, learning involves constructing one's knowledge from a shared rather than an individual's own experience. In Michael Long's view (cited in Brown, 2000), language development and social development are associated: language acquisition cannot be understood without analyzing a learner's cognitive development or social life in which he or she interacts with peers, teachers, or others. Vygotsky (1978) also state that learners construct the new language through socially mediated interaction, and the relationship between activities and learning in the social environment plays a significant role in the education process. This process creates a context for activity, especially for reflective thinking about that activity. Therefore, language learning can be the product of the thinking, that is, expressing ideas or reflecting after activities, learning, or interacting with people. Referring to the concepts of service learning, social interaction and reflection can be tightly linked to cognitive development and language development.

\section{Community-Based Learning and Teaching Programs}

CBL and research, known as service-learning, is an educational concept which is increasingly utilized as a teaching and learning strategy to support teaching (Glenn \& Coldthwaite, 2008), enrich the learning experience, teach social responsibility, and strengthen communities. CBL integrates meaningful service with instruction as well as reflection, and combines standard classroom work, specifically involving academic departments across the curriculum, with the movement of students out into the community. As Julier (2001) argue, service learning encourages students to think critically about diverse political or cultural issues, while also invigorating teachers and motivating students by engaging them in various kinds of community service as part of the course activity. Schutz and Gere (1998) also find a rationale for English studies taking up service learning as a bridging concept because both theoretically and practically fit particularly well in English departments that "foreground the ways people read and write, attend to cultural studies, and entertain questions about public policy" (p. 130). Learning is not individual or theoretically based, but should be related to real-life tasks and acquired via social practices.

Community service learning programs are a common component of higher education in many countries, but are not a common element of English foreign language departments in Taiwan. Jeavons (1995) conclude that they offer exceptional value to students by 1) helping them both develop better critical thinking skills and understand how the knowledge and techniques they are learning can be applied to real world problems, 2) helping them learn how to frame problems in comprehensive and practical ways, connecting different kinds of knowledge and experience so as to envision comprehensive solutions, and 3) helping them see why it matters whether they are involved in addressing the needs of the communities of which they are a part (p. 135). Many higher education institutions and discipline-specific associations have embraced service-learning to positively respond to community challenges and opportunities for collaboration. Incorporating service learning into the curriculum as a teaching pedagogy in higher education therefore seems to be an important issue.

\section{Identity as a Framing Concept in Teacher Education Research}

In the past 10 years, many researchers consider teachers' identity as a prominent framing concept and a useful analytical tool in the file of teacher education research (e.g., Farnsworth, 2010; Trent, 2010; Gee, 2001), but the term identity has been variously defined and conceptualized in different disciplines (e.g., Gee, 2001). The concept of identity can be used in ways in relation to the concept of self (Mead, 1934), and can be constructed through interacting with others in social contexts. Wenger (1998) and Gee (2001) both suggest that individuals should establish and create images of their own experience through engagement, and coordinate their own activities in groups to allow the group identity to be part of themselves as individual participants.

Therefore, teacher education programs play a crucial role and are considered to be the first and perhaps the most important stage in the development of student teachers' professional identity (Beijaard et al., 2004). While the process of being a teacher is complicated and not stable (Beijaard et al., 2004; Maclean \& White, 2007; Beauchamp \& Thomas, 2009), teacher identity helps in the decisions that STs make about their teaching practices, the content they teach, the goals they want to attain, the kinds of relationships they maintain with their students, and their professional development opportunities. Therefore, being a teaching is not only a matter of being seen as a teacher by oneself, but is an ongoing process of creating with others (Gee, 2001) and recreating and redefining the concept of teacher identity during the process of learning to teach in a given social context (Trent, 
2010; Gee, 2001). It is also a process of requiring and integrating the personal and professional aspects of becoming a teacher.

Some researchers have investigated the impact of constructing STs' identity, and have used different pedagogical tools such as reflective writing, collaborative reflection, autoethnography, and action research (Maclean \& White, 2007), as well as the influence of variables such as context (Schepens et al., 2009), motivation (Schepens et al., 2009), and prior experiences (Olsen, 2008) on the process of STs' identity formation. Each of these variables appears to have both positive and negative impacts on STs' identity. Thus, gaining a better understanding of the process of STs' identity formation and pedagogical tools could positively inform teacher education and research designs (Beauchamp \& Thomas, 2009).

Besides the significant impact of applying identity as an analytical tool in education programs, Medgyes (1994) raise the issue concerning non-native English-speaking teachers constructing their self-image and self-perceptions as English language teaching professionals. Trent (2011) and Park (2012) identify a number of factors of learning experience influencing non-native English-speaking teachers' professional identity formation, and other factors such as students' perceptions and attitudes (Amin, 1999), self-image and beliefs about teaching and learning (Rajagopalan, 2005), societal beliefs, and education initiatives (Careless, 2006). It is a trend in language teaching education to explore STs' identity and their perceptions of language teaching and learning. Therefore, it is significant for this study to explore the views of STs' identity development and to fill this gap in the second language teaching research domain.

\section{THE DESIGN OF THE STUDY}

\section{Participants and Research Setting}

In this study, I used qualitative research methods to explore participants' perceptions of language teaching and identity development based on building a holistic picture and reporting detailed views of information. This exploratory study has the capacity to gain in-depth and interpretive understanding of the construction process that participants employ in various contexts (Creswell, 2009). Therefore, the study explored elements and factors that may influence and be related to the participants' development of their second language teaching and identity in the Community-based Learning (CBL) program. In particular, I expected to explore some issues that STs encountered as they entered local communities.

The students I recruited for this study were DAE (Department of Applied English) students who, by applying for a two-semester second language teaching program (October 2015 to June 2016) at their university, expressed interest in teaching and Community-based Learning including Community Service Learning (CSL). The program provides research-based practical knowledge through connecting with a community. The overall mission of the program situates the preparation of the student-teachers (STs) in the instructional contexts of the school and community to develop their second language teaching, to strengthen the relationship between the communities and the university, and to create a social setting for the STs to construct their teacher identities and for the educators to understand the STs' perceptions of cultural or educational practices and value.

The program includes several design features such as teaching at public schools or in the community, and teaming up with faculty or administrators from schools to co-teach and work collaboratively with some classes. The school selected for this study is located in Kaohsiung and is called a "special remote school". The Ministry of Education uses this term to distinguish schools that are either very remote, economically weak, or in an Aboriginal area. There was a total of 50 students enrolled in the school in 2015. By partnering with this school, the university was able to place $40 \mathrm{DAE}$ students in the school where New Immigrant Children represented $11-16 \%$ of the student population, and the number of students from single-father, single-mother, and grandparent-led was around $25 \%$. Other voluntary activities the STs chose for their CSL experiences included helping out with organizing or hosting activities at school such as Christmas and New Year celebrations, English Winter Camps and English Club, as well as tutoring or teaching children learners at the public library and community center.

\section{Data Collection}

Three types of data were collected in order to answer the research questions. The primary form of data collection was narrative interviews with four STs (Chris, Jan, Doris, Ben all pseudonyms), all Taiwanese who had grown up in big cities. Each interview lasted for about 1 hour. These interviews were conducted on multiple occasions (2-4 sessions depending on schedules), both before and after their community and teaching experiences. As Brunner (1990) argued, personal narratives are one of the ways people make sense of the world around them. Reflection papers were the second type of data collection. Through reflection practices, the four participants were able to reflect on and integrate their personal experiences, beliefs, and values in respect to their teaching decisions. According to the STs' reflections, the researcher generated themes to refer to their concerns about their personal values of ST identity development and their new roles as language STs. Reflective practices included reflection meetings, narratives, papers, and reflective portfolios, which were mainly used as data collection tools to document the development of the STs' identity. Two rounds of classroom observation were to see STs' teaching practices, interactions, and negotiations with students in the classroom or types of behavior which occurred in the classroom. The observations provided more precise evidence and data sources for the data analysis.

\section{Data Analysis}

A socio-cultural discursive approach was applied as the framework of analysis for this study. The kind of teacher the study participants acted and interacted with, imagined, and presented themselves as were considered to interpret the 
ways they negotiated complex classroom interactions and the meaning made of their experiences in the construction of their teacher identities (Holland et al., 2001).

The initial data analysis began after collecting the reflection papers. The first interview was conducted before the reflection papers were analyzed, while the second interviews were conducted after the analysis. The reflection papers were content-analyzed by two educational researchers who analyzed each paper and the interview data according to themes, placing the data within an identified category or subcategory.

\section{FINDINGS}

\section{Personal Values of Teacher Identity and Language Teaching}

The results of this analysis revealed that when students come to understand the notion of personal values and of self as being a second language teacher, they may see themselves as having all the appropriate personal qualities for effective language teaching and as having pedagogical competence in CBL. It is not surprising therefore, that the personal value of education as well as of society and the personal qualities of teachers were portrayed as the qualities of the kind of teacher they wished to be. Chris said, as a citizen of Taiwan, "I feel that I should do something and support those people who are denied a good education or [the chance to be] a great language learner because they are educated in Aboriginal areas or born into minority groups." Continuing, she said "I believe that everyone in this country should have access to the same high quality education or training programs regardless of their socioeconomic background." Another participant, Jan, stated, "I want to be a facilitator in my English class because language teaching is not just for skills but is about moving humanity towards boundless potentials of responsibility, awareness, and intelligence." Similarly, Jan framed her ideal education as positive progress and a political act rather than as dissemination of knowledge. Doris also mentioned that "everyone should have an equal right to a range of high quality education no matter where they live or come from." Ben explained his understanding of minority groups and their language proficiency as follows:

I have no particular sense of belonging or responsibility toward their groups or communities, but I want to see, meet, and know them. Why do so many elementary students lack motivation to learn English? Sometimes people negatively label them [students from special remote areas and schools] as inferior, or as disadvantaged groups or castes like 'minorities'. Poverty, poor quality schooling, and powerlessness do not fully explain language minority failure in education.

Ben had a strong motivation to investigate his assumptions about this community. He used several terms such as "powerlessness, failure, inferior, and weak" to argue the concept of injustice noted throughout the society and the educational system. They all brought up the issue of having a good quality education and equal language learning environment for everyone.
In addition to their opinions and judgments of social, educational, economic, and political aspects, another theme particularly influenced and helped to define the STs' identity with respect to their backgrounds and prior experience. Chris mentioned that family values and community contexts had a great impact on her personal identity. Doris focused on aspects of socio-economic background and income level that can be translated into herself being an effective teacher or a more socially just educator. Doris gave a voice to low-income students and wanted to promote the issues of language teaching resources and equity through her teaching practices in CBL programs. Some reasons were reflective of and personal to the STs' prior experience. For example, Jan grew up in a moderately remote area with a large indigenous population where there was a lack of medical and educational resources. She said:

I was deeply affected by my language learning experience. My teacher always encouraged me to learn, to read, and to think differently, even though there were not many resources for reading or learning in my place... there were not many students in my class and many of them were not motivated to learn or study English.

Jan continued by stating some radically new ideas, and she believed that building critical thinking skills through reading is one of the essential factors to motivate students to learn. Chris added that "no other profession is more important than that of a teacher, and I am a creative and innovative person." Chris is able to enthuse and motivate others with new ideas, and carries them along to accomplish tasks. She wants to be a teacher who not only needs to step back and look inside herself but is willing to go a little further. Chris explained that "teachers need to be radically open themselves and be willing to accept students' voices so that we can think differently than we did before."

In each of these instances, Chris, Jan, Ben, and Doris' beliefs, prior learning experiences, and social values grounded their individual personal identities. In other words, these four participants' personal identities were constructed based on personal values of education as well as society and the personal qualities of teachers, but their role had not noticeably changed from transferring pedagogical values and knowledge to facilitating the learning process at this stage.

\section{Incorporating New Roles into Language Student- Teachers' Identity}

The STs incorporated new roles into their second language teaching in the CBL. As Maxine Greene (1981) stated, learning to teach is a process of identity development. While the four participants expressed the ways of selecting their new roles as L2 teachers, or of making personal choices about who they are, the process of teaching helps shape and construct their professional identities. During the CBL program, the participants' new identities as STs developed while learning to teach in the classroom. In their writing and reflecting upon their teaching experience, the four participants noted the various roles they saw and the issues they found becoming available to them as English teachers. 


\section{Role of Their Pedagogical Identity in Community-Based Learning}

The participants' new role of professional self, sense of cultural differences, and their positive involvement in the CBL benefited them in the construction of their teaching identity. Over the course of the CBL, Doris realized that interacting with teachers and students helped her continually develop the pedagogical identity she chose. At the beginning, she noted that she had a feeling of dissonance even though she wrote lesson plans and did teaching demonstrations at school. She said, "I have to replace my original assumption that the students' language proficiency is good and they are friendly and motivated to learn in class." Therefore, after coming back from her first teaching practice, Doris tried to adjust her teaching methods and strategies right away.

Chris stated that she had continued to develop her pedagogical identity through her observation of and interaction with others. Chris always observed her teachers or colleagues and tried to learn their positive characteristics and teaching strategies as much as possible. She continued by saying that "my teacher and my team member were unbelievable and are like good friends." She noticed that having a successful lesson requires mutual learning between teachers and students. The involvement and reciprocal interactions in the CBL are resources STs can draw upon as they negotiate their teacher identities.

The ongoing interaction with pupils is crucial. Chris said, "You can draw from their smiles, their liveliness and even learn from their perspectives on life." Chris continuously said that "teaching is not an easy job because it is a mission." In this context, the STs' own identities, their understanding of the context and of their students, and their experiences of language teaching and learning were considered to be important.

As previously mentioned, Doris' expectations regarding the students' level and teaching methods affected her pedagogical identity. Jan also addressed her hard time applying teaching methods for lower level language proficiency students, and tried to improve her teaching skills. Chris said that she had trouble preparing the first and second lessons and teaching materials, but found a criterion to evaluate her pupils' understanding of the subject. Chris said,

The main reason I had these problems was that I was not familiar with my pupils, so when the students had some positive responses, a question, even a smile, to my teaching, I realized that it was a successful lesson and it became my criterion for judging my own teaching... motivating and creating opportunities for lower level students to 'use' English in the classroom. I don't want to destroy their motivation for English learning. It is not the final teaching result [that is important] but the process toward that result, and my personal gain through that development process.

Doris, Jan, and Chris's ST identities had aspects that changed based on the learners and on what was taught. Their identity as STs shaped when they attempted to improve their teaching strategies and skills in terms of having a clear goal for their teaching and adjusting the teaching approach in
CBL. From the class observation, Jan also showed her understanding, tolerance and respect for cultural differences. ... one student always yelled out the orders at some certain students while playing games in English class...in the group work, some always kept silent and some were noisy...English, Taiwanese, Mandarin, Vietnamese were all in the same group. One student never followed the rules, another said the actual word or spoke their first language, Taiwanese, the other argued for points for individuals. I was extremely busy dealing with all of these situations...I knew I had to do something.

Jan's responses showed that she was sensitive to the beliefs of cultural differences. Today, apart from special needs students, general students, students of immigrant residents, Aboriginals, and students from low-income households all learn together in the same class. Therefore, creating a culturally responsive classroom is important because this exposure will enable students to be more tolerant of each other's differences and show them how to appreciate the rest of the world.

The CBL program contributed to the STs' personal identity growth but it took time for the process of growth. Jan said, "I have become more patient, and communicate with a sense of humor, so I feel more comfortable in the class. Teachers and students all need time to learn about a new multicultural setting and even need more time to adopt its norms." This change in Jan's awareness of cultural differences and her personality ended up helping her and consequently her pupils, her teaching and the context. Ben appreciated joining the CBL program as it provided him with opportunities for self-improvement. Ben admitted that the experience of teaching altered his concerns about dealing with unexpected events and helped him recognize the connection between the latent knowledge gained in his university courses and its application in naturalistic settings.

\section{Role of Social Expectations}

Besides understanding that children's situations at school are influenced by their parents' attitudes to education and by their comprehension of the teacher's roles, Ben stated that the expectations of society had a great impact upon his professional identity. Ben particularly pointed out that his professional identity is closely intertwined with the social context because the society prescribes the teacher as a good and disciplined person. Ben said, "I have to be careful about my use of language on Facebook and how I talk to my pupils." He realized that the teaching profession is significant for the development of pupils' learning as well as their personality, and it is not as easy as he had thought. He said, "I have to provide a model of behavior for the children, not only at school but also outside of school, which balances the parents' inadequate model." By reflecting on his experience, Ben was able to recognize places of dissonance and how he made meaning of that dissonance through interacting with students in the classroom, and his new ST identity intertwined with the social context. 


\section{Community-based Learning as A Negotiation Discourse}

CBL provides a place for negotiating identity and constructing knowledge outside the academic world. The participants of this study emphasized the academic benefits they received through the CSL program. Doris elaborated on these academic Discourses and saw how communities are relevant and important to teaching training and practice. Following is a description of one lesson in the CSL program,

In the class, my teacher brought up some social issues such as language teaching, students' motivation, family education, and human rights, so she invited faculty from public schools and people from the community to talk about these issues and join our discussion... They criticized the second language teaching methods and some social justice phenomena. They told a story about the grandparents' upbringing of young children... I really learned a lot from them and it was beyond my expectations.

Through the discourse of negotiation with community members, Doris gained a deep insight into some social issues, and explored her sense of social justice as a community member. Doris confidently expressed her opinions and suggested that language teaching programs should integrate the community into the classroom. Students need academic credits, but also need to learn from the outside world to enrich their learning experiences, increase their civic responsibility, and strengthen the community. In contrast, Ben did not present the same interest in the curriculum as Doris did. He said, "Students' English is at a variety of different levels, but I do not specifically pay attention to ensuring their individual improvement or learning. All I want to do is to make sure my students enjoy all the activities, speak English in the class, and have fun." Ben showed his engagement with the students or the local community and yielded limited information about his concerns in the curriculum. In the following excerpt, Ben shows his alignment with Taiwanese-speaking communities by emphasizing the school's language policy.

So many students come from Taiwanese-speaking families. They like to speak Taiwanese when they are placed in the same group in the classroom. In an English or Mandarin learning paradigm, students should speak English in the classroom, but we speak Taiwanese if we cannot negotiate the meaning well. I know the school's language policy. I certainly don't feel a need to force them to speak English the whole time in the classroom. If students cannot keep up with my teaching and feel panicked about speaking 'English' in English class, what is the purpose of English teaching? It's a matter of learning, not language only... [Students'] changes in behavior and confidence are from their freedom to choose when to start talking in English.

Ben shows his strong and positive connection with the Taiwanese-speaking community and drew upon enacting his ST identity through his narration of community Discourses. In the CBL program, the participants displayed their roles of personal self, their personal value of education and society, their sense of social responsibility or social justice, and the personal qualities of teachers were portrayed as the qualities of the teacher.

\section{DISCUSSION AND SUGGESTIONS}

This qualitative study applied a one-year community-based learning (CBL) program to second language teaching to explore four STs' personal and professional identities and their perspectives on learning to teach in the program. As many researchers have emphasized the importance of identity as being crucial to teacher education and language learning, this study also shows that incorporating CBL into a second language teaching program is a great way of teaching practices, and one which offers naturalistic settings of resources for STs engaged in identity negotiation and understanding of personal values, increasing their sense of social responsibility or social justice, and fashioning their personal and pedagogical identities.

The results of the analysis revealed some prominent issues of second language learning and teaching upon which prospective STs ponder in CBL programs.

Learning to teach is indeed a process, not a product, and it is a complex process deeply influenced by social interaction and the act of teaching itself. Reflecting McMahon's (1997) and Day's (2002) beliefs about learning, the purpose of learning should be related to real-life tasks to benefit individuals' learning and to foster their capacity to contribute to society. It is rational and crucial for higher education institutions or language teaching programs to integrate a more social perspective concept of the learning process such as involving $\mathrm{CBL}$ in academic work to positively respond to community challenges and opportunities for collaboration. It is a bridging concept of theoretically and practically learning to help students increase their knowledge development, and of negotiating multiple discourses in diverse social contexts. In this study, the individual participants saw and understood themselves regarding the appropriate personal qualities required for language teaching as they addressed the needs of the community and developed their personal values of a community of practice where learning happens in collaboration with others and through activities situated in that learning community. As Jeavons (1995) stated, CBL offers meaningful functions and exceptional value for students to enrich their learning experience in the real world and to strengthen communities.

The voice of these STs documenting their assumptions and understanding of teaching is more challenging due to the reality of teaching practices in a rural setting. For example, pupils' lower motivation to learn a second language and their language proficiency fell short of the STs' expectations, and the cultural and social factors challenged their personal and pedagogical identities when they took charge of a class. As second language teachers, they were also sensitive to the beliefs of differences and of creating a culturally responsive classroom. This exposure to cultural diversity enabled the STs to become aware of their tolerance levels and limits in terms of cultural differences. Citing another example, the STs encapsulated the roles of education in today's society with a strong voice. They believed that education is a civil rights issue for this generation, and is an issue of social justice. Stated another way, the STs attempted to frame education in terms of a right whereby citizens are entitled to receive a good quality education and language learning en- 
vironment. This exposure to multicultural complexities evidenced the rising levels of awareness of social justice and questioning of language learning and teaching approaches. However, when learning about a new multicultural setting, all language STs need more time to incorporate new roles into their identity and to adopt its norms.

The STs' perceptions of their personal values and pedagogical identity helped them develop a new role and transfer knowledge to facilitate the learning and teaching processes in the CBL program. The prominent notion of personal values and of self as a second language teacher was portrayed as the qualities of the kind of teacher they wished to be. More specifically, the STs' personal values of education, community contexts, and social values grounded their individual personal identities. They noticed that their involvement in the CBL was drawn upon as they negotiated their personal identities. Their personal values regarding communities and education can be translated into seeing themselves as successful teachers or more socially just teachers, but their new role as STs had not noticeably changed from transferring pedagogical values and knowledge to facilitating the learning process in the early stage of the CBL program.

The participants' new role of professional self gradually developed when they noticed that having a successful lesson requires mutual learning between teachers and students. The involvement and reciprocal interactions in the CBL are substantial resources STs can draw upon as they construct their teacher identities. Another aspect is based on learners and what is taught or what decisions are made. That is, their pedagogical identity continually developed and was shaped as they attempted to understand their pupils and modify their teaching approaches so as to have a clear goal of their teaching based on different contexts. The process of negotiating multiple discourses in diverse learning contexts had a great impact on their instructional decisions. This seems compatible with Kagan's (1992) argument. He stated that teachers' understanding of pupils could be used as a great source to modify and reconstruct their identity as STs.

STs' professional identity is closely intertwined with social contexts. The STs negotiated and incorporated a new role of social expectations into their language teaching practices in multicultural contexts. This can be illustrated by how they realize the role that society prescribes for a good teacher and a disciplined person. Therefore, the STs changed their views of the teaching profession and broadened their understanding of the meaning of their new role as language teachers. In these circumstances, the STs redefined the meaning of a 'good' language teacher in terms of increasing their concern about the actual practice of integrating linguistic knowledge, language-related experience, students' learning and personality, and social responsibilities. The findings of this study indicate that these are essential resources that STs can draw on as they negotiate and construct their identities as teachers.

As has been discussed, STs construct their identity in many ways. They have become more socially just teachers when they give a voice to low-income students and promote the issues of language teaching resources and equity through their teaching practices in the CBL program. Learn- ing through social interaction and in diverse social contexts is another dimension of language learning and negotiation of identity, as Gee (2001) claimed, specifically in curriculum and language teaching programs.

As I have found, learning to teach is an active, socialized, and contextualized process of constructing knowledge and identity. A well-designed language teaching program should have a central place in helping students to understand the pragmatic nature of the teaching profession and to increase their social responsibilities. The ultimate value of including $\mathrm{CBL}$ in the current language teaching coursework and programs is prominent because community teaching experiences provide STs with cultural resources for identity negotiation and opportunities for self-growth. A CBL program should be part of a coherent education program and language teaching program in Taiwan because the study supports the view of the concurrent development of their personal and professional identity as well as their sense of social responsibility or social justice in the program.

There are several implications of the findings of this study for teacher education or language teaching programs, in terms of their design and pedagogic practices; namely, educators should emphasize the goals of helping students develop a well-grounded understanding of their true personal values and personal growth, and increase their awareness of their social responsibilities in order to increase their understanding of social justice. Meanwhile, educators should find ways to support STs in negotiating multiple discourses in ways that engage critical reflection and shape their teacher identities. This study contributes to the ongoing discussion on the concept of social justice and developing personal growth experiences and identity for STs through interacting with the community and their teaching practices.

\section{REFERENCES}

Amin, N. (1999). Minority women teachers of ESL: Negotiating white English. In G. Braine (Ed.), Non-native educators in English language teaching (pp. 93-104). Mahwah, NJ: Lawrence Erlbaum Associates.

Assaf, L. C. (2005). Exploring identities in a reading specialization programme. Journal of Literacy Research, 37(2), 201-236.

Atkinson, D. (2002). Toward a sociocognitive approach to second language acquisition. Modern Language Journal, 86, 525-545.

Atkinson, D. (2004). Theorising how student teachers form their identities in initial teacher education. British Educational Research Journal, 30 (3), 379-394.

Bakhtin, M. M. (1981). The dialogic imagination: four essays (C. Emerson and M. Holquist, Trans.). In M. Holquist (Ed.). Austin: University of Texas Press.

Beauchamp, C., \& Thomas, L. (2009). Understanding teacher identity: An overview of issues in the literature and implications for teacher education. Cambridge Journal of Education, 39(2), 175-189.

Beijaard, D., Meijer, P. C., \& Verloop, N. (2004). Reconsidering research on teachers' professional identity. Teaching and Teacher Education, 20, 107-128. 
Brown, D. H. (2000). Principles of language learning and teaching ( $4^{\text {th }}$ ed.). White Plains, NY: Addison Wesley Longman, Inc.

Bruner, J. S. (1990). Acts of meaning. Cambridge, MA: Harvard University Press.

Bullough, R. V. (1997). Practicing theory and theorizing practice. In J. Loughran \& T. Russell (Eds.), Purpose, passion and pedagogy in teacher education (pp. 13-31). London: Falmer Press.

Carless, D. (2006). Collaborative EFL teaching in primary schools. ELT Journal, 60(4), 328-335.

Creswell, J. W. (2009). Research design: Qualitative and quantitative approaches ( $3^{\text {rd }}$ ed.). Thousand Oaks, CA: Sage.

Day, R. R. (2002). Critical thinking in the EFL classroom. Selected papers from the eleventh international symposium on English teaching/fourth Pan-Asian conference, 72-78. Taipei: Crane.

Day, C., \& Kington, A. (2008). Identity, well-being and effectiveness: The emotional contexts of teaching. Pedagogy, Culture \& Society 16 (1), 7-23.

Deans, J. (2000). Writing partnerships: Service-learning in composition. Urbana,IL: National Council of Teachers of English.

Fan, Y. (2013). Preparing teacher candidates for English language learners through service-learning. Gateways: International Journal of Community Research and Engagement, 6, 77-92.

Farnsworth, V. (2010). Conceptualizing identity, learning and social justice in community-based learning. Teaching and Teacher Education, 26, 1481-1489.

Firth, A., \& Wagner, J. (1997). On discourse, communication, and (some) fundamental concepts in SLA research. The Modern Language Journal, 81, 237-259.

Gee, J. P. (1999). An introduction to discourse analysis: Theory and method. London: Routledge.

Gee, J. P. (2001). Identity as an analytic lens for research in Education. Review of Research in Education, 25, 99-125.

Glenn, C., \& Goldthwaite, A. M. (2008). The St. Martin's guide to teaching writing ( $6^{\text {th }}$ ed.). Boston, New York: Bedford/St.Martin's

Greene, M. (1981). Contexts, connections, and consequences: The matter of philosophical and psychological foundations. Journal of Teacher Education, 31, 31-37.

Holland, D., Lachicotte, W., Jr., Skinner, D., \& Cain, C. (2001). Identity and agency in cultural worlds. Boston, MA: Harvard University Press.

Jeavons, H. T. (1995). Service-Learning and Liberal Learning: A Marriage of Convenience. Michigan Journal of Community Service Learning, 2(1), 134-140.

Julier, L. (2001). Community- service pedagogy. In Tate, G., Rupiper, A., \& Schick, S (Eds.), A Guide to Composition Pedagogies. New York: Oxford.
Kagan, D. (1992). Implication of research on teacher beliefs. Educational Psychologist, 27(1), 65-91.

Larsen-Freeman, D. (2007). Reflecting on the cognitive-social debate in second language acquisition. The Modern Language Journal, 91, 773-787.

Long, M. (2007). Problems in SLA. Mahwah, NJ: Erlbaum.

Maclean, R., \& White, S. (2007). Video reflection and the formation of teacher identity in a team of pre-service and experienced teachers. Reflective Practice, 8 47-60.

McMahon, M. (1997, December). Social Constructivism and the World Wide Web - A Paradigm for Learning. Paper presented at the ASCILITE conference. Perth, Australia.

Mead, G. H. (1934). Mind, self, and society. Chicago: The University of Chicago Press.

Medgyes, P. (1994). The non-native teacher. London, England: Macmillan Publishers.

Olsen, B. (2008). Reasons for entry into the profession illuminate teacher identity Development. Teacher Education Quarterly, 35(3), 23-40.

Park, G. (2012). "I am never afraid of being recognized as an NNET": One teacher's journey in claiming and embracing her nonnative-speaker identity. TESOL Quarterly, 46(1), 127-151.

Poulou, M. (2007). Student-teachers' concerns about teaching practice. European Journal of Teacher Education, 30, 91-110.

Rajagopalan, K. (2005). Non-native speaker teachers of English and their anxieties: Ingredients for an experiment in action research. In E. Llurda (Ed.), Nonnative language teachers: Perceptions, challenges and contributions to the profession (pp. 183-303). New York, NY: Springer.

Schepens, A., Aelterman, A., \& Vlerick, P. (2009). Student teachers' professional identity formation: between being born as a teacher and becoming one, Educational Studies, 35 (4), 361-378.

Schutz, A., \& Gere, A. R. (1998). Service learning and English studies: Rethinking 'public' service. College English, 60(2), 129-49.

Trent, J. (2010). Teacher education as identity construction: Insights from action research. Journal of Education for Teaching, 36(2), 53-168.

Trent, J. (2011). "Four years on, I'm ready to teach": Teacher education and the construction of teacher identities. Teachers and Teaching: Theory and Practice, 17(5), 529-543.

Vygotsky, L. S. (1978). Mind and society: The development of higher mental processes. Cambridge, MA: Harvard University Press.

Wenger, E. (1998). Communities of practice: Learning, meaning, and identity. Cambridge: Cambridge University Press.

Zuengler, J., \& Miller, E. (2006). Cognitive and sociocultural perspectives: Two parallel worlds? TESOL Quarterly, 40, 35-58. 